\title{
Penerapan Bimbingan Belajar dalam Meningkatkan Hasil Belajar Peserta Didik di SMP Negeri 12 Kota Bandar Lampung Tahun Pelajaran 2015/2016
}

\author{
Rifda El Fiah, Adi Putra Purbaya
}

Dosen Fakultas Tarbiyah dan Keguruan, IAIN Raden Intan Lampung

Diterima: 20 April 2016. Disetujui: 17 Juli 2016. Dipublikasikan: Nopember 2016

\begin{abstract}
Abstrak: Guru Bimbingan dan Konseling memiliki tugas dan tanggung jawab yang berat dan besar baik untuk mengatasi permasalahan yang dihadapi peserta didik juga memberikan bimbingan belajar agar hasil belajar peserta didik dapat meningkat. Bimbingan belajar adalah suatu proses pemberian bantuan kepada siswa dalam menyelesaikan masalah-masalah belajar yang dihadapi peserta didik, sehingga tujuan dari belajar akan tercapai imbingan belajar adalah suatu kegiatan bantuan belajar yang bertujuan agar peserta didik mendapat mencapai hasil belajar secara optimal. Hasil belajar peserta didik khususnya mata pelajaran Pendidikan Agama Islam di SMP Negeri 12 Kota Bandar Lampung ada yang dibawah Kriteria Ketuntasan Minimal (KKM) yang telah ditetapkan yaitu 70. Kondisi ini mengharuskan guru Bimbingan dan Konseling menerapkan bimbingan belajar agar hasil belajar peserta didik dapat meningkat, sehingga rumusan masalah yang diajukan "Bagaimana penerapan bimbingan belajar dalam meningkatkan hasil belajar peserta didik di SMP Negeri 12 Kota Bandar Lampung Tahun Pelajaran 2015/2016"?. Penelitian ini menggunakan pendekatan deskriptif kualitatif yaitu analisis data yang menekankan pada makna, penalaran, definisi suatu situasi tertentu (dalam konteks tertentu) serta menggambarkan apa adanya mengenai perilaku obyek yang sedang diteliti. Alat pengumpul data yaitu metode observasi, interview dan dokumentasi, sedangkan dalam pengolahan dan analisis data langkah yang digunakan yaitu reduksi data, display data yaitu proses pemilihan dan penyederhanaan data, display daya yaitu penyajian data secara utuh dan verifikasi data yaitu proses penarikan kesimpulan. Dengan menggunakan metode tersebut di atas dapat disimpulkan bahwa penerapan bimbingan belajar dalam meningkatkan hasil belajar peserta didik di SMP Negeri 12 Kota Bandar Lampung Tahun Pelajaran 2015/2016 adalah dengan menunjukkan cara-cara belajar yang efektif yaitu memberikan bimbingan teknis tentang belajar sehingga kesulitan belajar yang dialami dapat diselesaikan, membantu mempersiapkan diri dalam mengerjakan tugas dan ujian sehingga memiliki persiapan dalam menerima ujuan dan tugas-tugas yang diberikan, menunjukkan cara-cara menghadapi kesulitan dalam belajar yaitu dengan mengidentifikasi kasus, mengidentifikasi masalah, melakukan diagnosis, melakukan prognosis, melakukan treatment dan melakukan evaluasi dan tindak lanjut dan membantu dalam pengembangan bakat dan kariernya dimasa depan yaitu dengan mengenal potensi, minat, bakat yang ada dalam diri peserta didik kemudian memberikan bimbingan untuk menentukan pilihan akan melanjutkan ke jurusan apa setelah lulus sekolah.
\end{abstract}

Kata kunci: Penerapan bimbingan belajar; hasil belajar

\section{Pendahuluan}

Pelayanan bimbingan dan konseling di SMP meliputi bidang bimbingan pribadi, bidang bimbingan sosial, bidang bimbingan belajar dan bidang bimbingan karier. Salah satu bidang bimbingan yang membantu siswa mengembangkan diri berkenaan dengan sikap dan kebiasaan belajar yang baik untuk menguasai pengetahuan dan keterampilan serta menyiapkan melanjutkan pendidikan pada tingkat yang lebih tinggi adalah bimbingan belajar.

Bimbingan belajar adalah "bimbingan dalam hal menemukan cara belajar yang tepat, dalam memilih program setudi yang sesuai, dan dalam mengatasi kesukaran-kesukaran yang timbul berkaitan dengan tuntunan-tuntunan belajar di suatu institusi pendidikan". Berdasarkan uraian di atas dapat diperjelas bahwa bimbinganbelajar adalah suatu bantuan yang diberikan pada siswa untuk mengatasi masalah-masalah dalam belajar sehingga mendapat hasil yang baik. Bidang bimbingan dan konseling dapat dilaksanakan melalui berbagai jenis layanan. Layanan bimbingan dan konseling meliputi layanan orientasi, layanan pembelajaran, layanan penempatan dan penyaluran, layanan konseling individu, layanan konseling kelompok, layanan bimbingan kelompok dan layanan informasi. Salah satu jenis layanan bimbingan dan konseling yang memungkinkan siswa mengembangkan diri berkenaan dengan sikap dan 
kebiasaan belajarnya, serta berbagi aspek tujuan kegiatan belajar lainya adalah layanan pembelajaran.

Layanan pembelajaran yaitu layanan bimbingan dan konseling yang memungkinkan peserta didik mengembangkan peserta didik mengembangkan diri berkenaan dengan sikap dan kebiasaan belajar yang baik, materi belajar yang cocok dengan kecepatan dan kesulitan belajarnya, serta tuntunan kemampuan yang berguna dalam kehidupan dan perkembangan dirinya.

Tujuan dari layanan pembelajaran bidang bimbingan belajar adalah agar siswa mampu menguasai pengetahuan dan dapat mengembangkan keterampilan yang diperoleh dari sekolah, sehingga dengan diberikannya layanan pembelajaran bidang bimbingan belajar maka diharapkan siswa termotivasi dalam mencapai prestasi yang optimal dan mampu menerapkan ilmu pengetahuan yang telah didapat dari sekolah.

Adapun bentuk-bentuk pelayanan yang diberikan oleh guru bimbingan dan konseling terhadap peserta didik adalah sebagai berikut :

a. pelayanan individu

Pelayanan individu adalah salah satu bimbingan atau penyerahan yang diberikan guru Bimbingan Konseling kepada peserta didik secara perorangan, pelayanan ini biasanya diberikan pada peserta didik yang mempunyai masalah pribadi. Pelayanan secara individu ini dapat dilakukan guru bimbingan dan konseling di ruang bimbingan dan konseling atau kunjungan ke rumah.

b. pelayanan kelompok

Pelayanan kelompok yaitu suatu pelayanan atau bimbingan yang dilakukan guru Bimbingan Konseling secara berkelompok. Bimbingan ini biasa diberikannya diberikan pada peserta didik yang mempunyai masalah secara kelompok, bimbingan bisa diberikan di dalam kelas, di masjid atau di aula.

Adapun indikator guru Bimbingan Konseling menerapkan bimbingan belajar dalam meningkatkan hasil belajar adalah sebagai berikut.

1. Menunjukkan cara-cara belajar yang efektif

2. Membantu mempersiapkan diri dalam mengerjakan tugas dan ujian

3. Menunjukkan cara-cara menghadapi kesulitan dalam belajar

4. Membantu dalam pengembangan bakat dan kariernya dimasa depan

Berdasarkan hasil interview pada saat pra survey terhadap guru Bimbingan dan Konseling di SMP Negeri 12 Kota Bandar Lampung diperoleh keterangan sebagai berikut.

Sebagai guru Bimbingan Konseling saya telah melaksanakan tugas dan tanggung jawab yang diberikan sekolah khususnya dalam hal memberikan bimbingan belajar kepada peserta didik terhadap peserta didik agar hasil belajarnya meningkat. Dalam penerapannya hal-hal yang saya lakukan adalah mencarikan cara-cara belajar yang efisien dan efektif bagi seorang anak atau sekelompok anak, menunjukkan cara-cara mempelajari sesuatu dan menggunakan buku pelajaran, memberikan informasi (saran dan petunjuk) bagaimana memanfaatkan perpustakaan, membuat tugas sekolah dan mempersiapkan diri dalam ulangan dan ujian, memilih suatu bidang studi (mayor atau minor) sesuai dengan bakat, minat, kecerdasaan, citacita dan kondisi, fisik atau kesehatannya, menunjukkan cara-cara menghadapi kesulitan dalam bidang studi tertentu, menentukan pembagian waktu dan perencanaan jadwal belajarnya dan memilih pelajaran tambahan baik yang berhubungan dengan pelajaran di sekolah maupun untuk pengembangan bakat dan kariernya dimasa depan".

Namun penerapan bimbingan belajar yang telah dilakukan oleh guru Bimbingan Konseling tersebut belum sepenuhnya berhasil, hal ini dapat dilihat dari indikasi peserta didik yang hasil belajarnya belum tuntas dan dibawah Kriteria Ketuntasan Minimal (KKM) khusus 
untuk mata pelajaran Pendidikan Agama Islam (dipilihnya mata pelajaran Penddikan Agama Islam karena satu-satunya mata pelajaran yang berbasis keagamaan dan sesuai dengan spesialisasi keahlian penulis), sebagaimana tabel dibawah ini :

Tabel 1. Hasil Belajar Mata Pelajaranendidikan Agama Islam Peserta Didik Kelas VIII-4 SMP N 12 Kota Bandar Lampung

\begin{tabular}{|c|l|c|c|l|}
\hline No & \multicolumn{1}{|c|}{ Nama } & KKM & Nilai & \multicolumn{1}{|c|}{ Keterangan } \\
\hline 1 & Ade Saputra & 70 & 60 & Tidak tuntas \\
\hline 2 & Adi Prasetyo & 70 & 75 & Tuntas \\
\hline 3 & Ahmad Soleh & 70 & 75 & Tuntas \\
\hline 4 & Angga Nursadi & 70 & 55 & Tidak tuntas \\
\hline 5 & Ayub & 70 & 70 & Tuntas \\
\hline 6 & Agung Nurhafizi & 70 & 60 & Tidak tuntas \\
\hline 7 & Almutadin & 70 & 55 & Tidak tuntas \\
\hline 8 & Adtya Febrian & 70 & 70 & Tuntas \\
\hline 9 & Budi Setiawan & 70 & 75 & Tuntas \\
\hline 10 & Dwi Atuti & 70 & 80 & Tuntas \\
\hline 11 & Diki Sumarwan & 70 & 55 & Tidak tuntas \\
\hline 12 & Debi Setiawan & 70 & 75 & Tuntas \\
\hline 13 & Ema Lailia & 70 & 80 & Tuntas \\
\hline 14 & Faiar Saputra & 70 & 75 & Tuntas \\
\hline 15 & Iqbal Tri Saputra & 70 & 55 & Tidak tuntas \\
\hline 16 & Kartini Juniar & 70 & 60 & Tidak tuntas \\
\hline 17 & M. Joni & 70 & 55 & Tidak tuntas \\
\hline 18 & Noviana Lestari & 70 & 70 & Tuntas \\
\hline 19 & Oka Santosa & 70 & 75 & Tuntas \\
\hline 20 & Puii Nurianah & 70 & 70 & Tuntas \\
\hline 21 & Ratna Sari & 70 & 60 & Tidak tuntas \\
\hline 22 & Renita & 70 & 55 & Tidak tuntas \\
\hline 23 & Riki Setiawan & 70 & 60 & Tidak tuntas \\
\hline 24 & Rahmat Dani & 70 & 70 & Tuntas \\
\hline 25 & Rian Setiawan & 70 & 75 & Tuntas \\
\hline 26 & Rohiyawati & 70 & 75 & Tuntas \\
\hline 27 & Sella Nurmaulidina & 70 & 80 & Tuntas \\
\hline 28 & Sartani & 70 & 60 & Tidak tuntas \\
\hline 29 & Siska Julianti & 70 & 75 & Tuntas \\
\hline 30 & Silvia Veronika & 70 & 75 & Tuntas \\
\hline 31 & Sinta Yunani & 70 & 55 & Tidak tuntas \\
\hline 32 & Siti Komaria & 70 & 70 & Tuntas \\
\hline 33 & Umaroh & 70 & 75 & Tuntas \\
\hline 34 & Wahyu Aji & 70 & 55 & Tidak tuntas \\
\hline 35 & Yoga Ardiansyah & 70 & 60 & Tidak tuntas \\
\hline & Sumber : Dokumentasi Legger & Kelas VIII-4 SMPN 12 KotaBandar Lampung \\
\hline
\end{tabular}

Berdasarkan tabel di atas jelas bahwa peserta didik kelas VIII-4 SMP Negeri 12 Kota Bandar Lampung dari 35 orang yang hasil belajarnya tuntas berjumlah 20 orang atau $57.1 \%$ sedangkan yang tidak tuntas belajar dan dibawah Kriteria Ketuntasan Minimal (KKM) 70 berjumlah 15 orang atau $42.9 \%$.

Berdasarkan uraian di atas diperoleh gambaran bahwa masih ada peserta didik kelas VIII-4 di SMP Negeri 12 Kota Bandar Lampung yang hasil belajar mata pelajaran Pendidikan Agama Islam di bawah Kriteria Ketuntasan Minimal (KKM). Kondisi di atas memotivasi 
peneliti untuk memecahkan permasalahan yang terjadi dan dapat dilakukan sesuai waktu yang tersedia, hemat biaya dan daya dukung lain yang dapat memperlancar dalam penelitian ini. Maka peneliti akan mengadakan penelitian dengan judul "Penerapan Bimbingan Belajar dalam Meningkatkan Hasil Belajar Peserta Didik di Sekolah Menengah Pertama (SMP) Negeri 12 Kota Bandar Lampung Tahun Pelajaran 2015/2016”.

Sebelum menguraikan pengertian bimbingan konseling belajar, terlebih dahulu akan diuraikan pengertian bimbingan, konseling dan belajar. Bimbingan merupakan terjemahan dan "guidance" yang berasal dan bahasa Inggris. Secara harfiah, istilah "guidance" dan akar kata "guide" berarti (1) mengarahkan (to direct), (2) memandu (to pilot), (3) mengelola (to manage) dan (4) menyetir (to steer). Menurut Dewa Ketut Sukardi, bahwa "bimbingan adalah merupakan proses pemberian bantuan kepada seseorang atau kelompok orang secara terus menerus dan sistematik oleh guru pembimbing agar individu atau kelompok individu menjadi pribadi yang mandiri". Belajar menurut Winkel adalah "semua aktivitas mental atau psikis yang berlangsung dalam interaksi aktif dalam lingkungan, yang menghasilkan perubahanperubahan dalam pengelolaan pemahaman".

Menurut Kartini Kartono, belajar merupakan proses perbuatan yang dilakukan dengan sengaja, yang kemudian menimbulkan perubahan, yang keadaannya berbeda dari perubahan yang ditimbulkan oleh lainnya. Sifat perubahannya relatif permanen, tidak akan kembali kepada keadaan semula. Tidak bisa diterapkan pada perubahan akibat situasi sesaat, seperti perubahan akibat kelelahan, sakit, mabuk, dan sebagainya.

Berdarkan uraian di atas dapat diperjelas bahwa bimbingan belajar adalah suatu proses pemberian bantuan kepada siswa dalam menyelesaikan masalah- masalah belajar yang dihadapi siswa, sehingga tujuan dari belajar akan tercapai imbingan belajar adalah suatu kegiatan bantuan belajar kepada siswa atau peserta didik yang bertujuan agar siswa mendapat mencapai prestasi belajar secara optimal.

2. Tujuan dan Fungsi Bimbingan Belajar

Menurut teori humanistik, tujuan belajar adalah untuk memanusiakan manusia. Proses belajar dianggap berhasil apabila si pelajar mampu memahamidirinya dan lingkungannya. Sedangkan menurut teori, belajar adalah "usaha memahami perilaku belajar dari sudut pandang pelakunya, bukan dari sudut pandang pengamatnya, akan tetapi dunia modern, lebih berpegang pada teori belajar humanistic".

Sedangkan menurut Rohman Ali, yang terpenting dalam proses pembelajaran untuk mencapai tujuan- tujuan belajar itu, yakni :

a. Menjadi manusia berarti memiliki kemampuan wajar untuk belajar b. Siswa yang akan mempelajari hal bermakna bagi dirinya

b. Pengorganisasian bahan pengajaran d. Belajar relevan/relative.

Apabila kesemuanya di gabung, maka dapat di peroleh penjelasan bahwa siswa mempunyai personal untuk belajar secara wajar. Siswa belajar supaya pandai adalah benar, dengan catatan materi pelajaran itu tidak di paksakan dan materi pelajaran itu akan di serap sesuai kemampuan siswa. Dalam pencapaian tujuan belajar ini sangat di harapkan adanya perorganisasikan bahan pengajaran supaya sesuai dengan dunia persepsi siswa. Belajar relevan berarti mempelajari hal penting bagi dirinya dan relative terhadap perubahan dunia social, semua menuntut perubahan dan perubahan ini akan di serap siswa juga pada akhirnya. Intinya, tidak ada paksaan lagi dalam proses pencapaian tujuan belajar Fungsi utama dari bimbingan belajar adalah membantu murid dalam masalah masalah pribadi dan sosial yang berhubungan dengan pendidikan dan pengajaran atau penempatan dan juga menjadi perantara dari siswa dalam hubunganya dengan para guru maupun tenaga administrasi. Ada beberapa fungsi dari bimbingan belajar yaitu sebagai berikut: 
a. Fungsi kognitif

Melalui fungsi kognitif manusia menghadapi objek-objek dalam suatu bentuk representatif yang menghadirkan semua objek itu dalam kesadaran. Hal ini paling jelas nampak dalam aktivitas mental berfikir.

1) Taraf intelegensi-daya kreatifitas.Istilah intelegensi dapat diartikan dalam dua cara yaitu arti luas dan arti sempit.

a) Arti luas yaitu kemampuan untuk mencapai prestasi yang didalamnya berpikir memegang peranan. Prestasi itu dapat diberikan dalam berbagai bidang kehidupan, seperti pergaulan sosial, teknis, perdagangan, pengaturan rumah tangga dan belajar di sekolah.

b) Arti sempit yaitu kemampuan untuk mencapai prestasi di sekolah, yang didalamnya berpikir memegang peranan pokok. Intelegensi dalamDalam pencapaian tujuan belajar ini arti ini kerap disebut kemampuan sangat di harapkan adanya intelektual atau kemampuan akademik.

2) Bakat khusus

Bakat khusus merupakan kemampuan menonjol di suatu bidang tertentu, misalnya di bidang studi matematika atau bahasa asing. Orang sering berpendapat, bahwa semua bakat khusus merupakan sesuatu yang langsung diturunkan oleh orang tua, misalnya bakat khusus di bidang matematika diperoleh dari orang tua melalui proses generasi biologis. Pendapat ini ternyata tidak benar. Bakat khusus adalah sesuatu yang dibentuk dalam kurun waktu sejumlah tahun dan merupakan perpaduan dari taraf intelegensi pada umumnya (general ability), komponen intelegensi tertentu, pengaruh pendidikan dalam keluarga dan disekolah, minat dari subjek sendiri.

3) Organisasi kognitif

Organisasi kognitif menunjuk pada cara materi yang sudah dipelajari, disimpan dalam ingatan, apakah tersimpan secara sistematis atau tidak. Hal ini sangat bergantung pada cara materi dipelajari dan diolah, makin mendalam dan makin sistematis pengolahan materi pelajaran, makin baiklah taraf organisasi dalam ingatan itu sendiri.

4) Kemampuan berbahasa

Kemampuan berbahasa mencakup kemampuan untuk menangkap intisuatu bacaan dan merumuskan pengetahuan dan pemahaman yang diperoleh itu dalam bahasa yang baik, sekurang-kurangnya bahasa tertulis. Mengingat kaitan yang ada antara berpikir yang tepat dan berbahasa yang benar, maka tidak mengherankan bahwa siswa yang kurang mampu berbahasa, tertinggal dibelakang dibanding dengan siswa yang berbahsa baik.

5) Daya fantasi

Daya fantasi berupa aktifitas kognitif yang mengandung banyak fikiran dan sejumlah tanggapan, yang bersama-sama menciptakan sesuatu dalam alam kesadaran. Daya fantasi dibedakan antara fantasi yang disadari dan yang tidak disadari. Misalnya, seorang sastrawan yang mengarang kisah roman, yang bergerak dalam alam fantasi secara sadar.

6) Gaya belajar

Gaya belajar merupakan cara belajar yang khas bagi siswa. Gaya belajar mengandung beberapa komponen antara lain: gaya kognitif dan tipe belajar. Gaya kognitif adalah cara khas yang digunakan seseorang dalam mengamati dan beraktifitas mental dibidang kognitif, cara khas ini bersifat sangat individual yang kerap kali tidak disadari dan, sekali terbentuk, cenderung bertahan terus.

b. Fungsi konatif-dinamik

Fungsi psikis ini berkisar pada penentuan suatu tujuan dan pemenuhan suatu kebutuhan yang disadari dan dihayati. Semakin tinggi tahapan perkembangan anak, semakin boleh 
diharapakan bahwa siswa mampu berpartisipasi dalam proses belajar mengajar secara aktif dengan suatu tujuan. Fungsi psikis terdiri dari :

1) Karakter-hasrat-berkehendak

Karakter atau watak menunjuk pada suatu aspek dalam kepribadian. Yang mana karakter ini iyalah keseluruhan hasrat pada manusia yang terarah pada suatu tujuan yang mengandung nilai moralitas. Dalam "berhasrat" orang mencari apa yang memberikan kepuasan padanya dan menyingkiri apa yang tidak memuaskan baginya. Seseorang mungkin berhasrat kuat dan memiliki kehendak yang tekun untuk mencapai sesuatu yang memberikan kepuasan padanya, tetpi ini belum berarti bahwa orang itu berkarakter atau berwatak baik. Tujuan yang ingin dicapai masuh harus dinilai dari segi moralitas, apakah termasuk hal yang baik atau hal yang buruk.

2) Motivasi belajar

Motivasi belajar adalah keseluruhan daya penggerak psikis didalam diri siswa yang menimbulkan kegiatan belajar, menjamin kelangsungan kegiatan belajar dan memberikan arah pada kegiatan belajar itu demi mencapai suatu tujuan. Motivasi belajar memgang peranan penting dalam memberikan gairah atau semangat dalam belajar, sehingga siswa yang bermotivasi kuat memiliki energi banyak untuk melakukan kegiatan belajar.

c. Fungsi afektif

Di dalam perasaan manusia mengadakan penilaian terhadap semua objek yang dihadapi, dihayatinya apakah suatu benda, suatu peristiwa atau seseorang, baginya berharga atau bernilai atau tidak. Bila objek itu dihayati sebagai sesuatu yang berharga maka timbulah perasaan senang. Alam perasaan seolah- olah terdiri dari beberapa lapisan yang berbedabeda peranannya terhadap semangat belajar. Kenyataan ini akan diuraikan dibawah ini:

1) Temperamen

Pada setiap orang, alam perasaan memiliki sifat-sifat umum tertentu. Ada orang yang pada umumnya cenderung berperasaan sedih dan pesimis, ada pula yang biasanya berperasaan gembira dan optimis. Ini dikenal dengan istilah "stemming dasar" atau nada dasar alam prasaan yang lebih kurang menetap.

2) Perasaan

Perasaan yang dimaksud disini adalah momentan dan intensional. Momentan berarti bahwa perasaan timbul pada saat tertentu. Intensional berarti bahwa reaksi prasaan diberikan terhadap sesuatu, seseorang atau situasi tertentu. Apabila situasi berubah maka prasaan berganti pula. Misalnya, bila guru sedang memarahi siswa dalam kelas mereka mungkin merasa takut, tapi bebrapa waktu kemudian prasaan itu hilang dan diganti perasaan lega, bila guru menceritakan sesuatu lelucon untuk meringankan suasana yang menjadi terlalu tegang

3) Sikap

Sikap yaitu orang yang bersikap tertentu cenderung menerima atau menolak suatu objek bedasarkan penilaian terhadap objek itu sebagai hal yang berguna atau berharga baginya atau tidak. Dengan demikian siswa yang memandang belajar disekolah pada umumnya, atau bidang studi tertentu, sebagai sesuatau yang sangat bermanfaat baginya, akan memiliki sifat positif, bagitu juga dengan sebaliknya

4) Minat

Minat yaitu diartikan sebagai kecenderungan subyek yang menentap untuk merasa tertarik pada bidang studi atau pokok bahasan tertentu dan merasa senang mempelajari materi itu. 


\section{d. Fungsi sensorik-motorik}

Kemampuan yang dimiliki siswa dibidang psikomotorik, juga merupakan bagian dari keadaan awal dipihak siswa, yang dapat menghambat atau membantu disemua proses belajar mengajar atau paling sedikit, dalam proses belajar yang harus mengahasilkan keterampilan motorik. Perolehan kemampuan yang dimaksud antara lain, kecepatan menulis, kecepatan berbicara dan artikulasi kata- kata, menggunakan alat-alat menggunting, memotong dan lain-lain.

Hasil belajar merupakan "perubahan perilaku yang diperoleh pembelajar setelah mengalami aktivitas belajar". Sedangkan pendapat lain menyatakan bahwa hasil belajar adalah "kemampuan yang dimiliki peserta didik setelah ia menerima pengalaman belajarnya". Berdasarkan pengertian di atas dapat dipahami bahwa hasil belajar adalah suatu kemampuan atau keterampilan yang dimiliki oleh peserta didik setelah mengalami aktivitas belajar. Hasil belajar yang dicapai peserta didik melalui proses belajar mengajar yang optimal ditunjukkan dengan ciri-ciri sebagai berikut:

a. Kepuasan dan kebanggaan yang dapat menumbuhkan motivasi belajar intrinsik pada diri peserta didik. Peserta didik tidak mengeluh dengan prestasi yang rendah dan ia akan berjuang lebih keras untuk memperbaikinya atau setidaknya mempertahankan apa yang telah dicapai.

b. Menambah keyakinan dan kemampuan dirinya, artinya ia tahu kemampuan dirinya dan percaya bahwa ia mempunyai potensi yang tidak kalah dari orang lain apabila ia berusaha sebagaimana mestinya.

c. Hasil belajar yang dicapai bermakna bagi dirinya, seperti akan tahan lama diingat, membentuk perilaku, bermanfaat untuk mempelajari aspek lain, kemauan dan kemampuan untuk belajar sendiri dan mengembangkan kreativitasnya.

d. Hasil belajar yang diperoleh peserta didik secara menyeluruh (komprehensif), yakni mencakup ranah kognitif, pengetahuan atau wawasan, ranah afektif (sikap) dan ranah psikomotorik (keterampilan atau perilaku).

e. Kemampuan peserta didik untuk mengontrol atau menilai dan mengendalikan diri terutama dalam menilai hasil yang dicapainya maupun menilai dan mengendalikan proses dan usaha belajarnya".

Berdasarkan uraian di atas jelas bahwa hasil belajar merupakan suatu perubahan yang berupa perubahan tingkah laku, pengetahuan dan sikap yang diperoleh seseorang setelah melakukan proses kegiatan belajar. Hasil belajar digunakan oleh guru untuk dijadikan ukuran atau kriteria dalam mencapai suatu tujuan pendidikan. Hal ini dapat tercapai apabila peserta didik sudah memahami belajar dengan diiringi oleh perubahan tingkah laku yang lebih baik.

Hasil belajar merupakan hal yang dapat dipandang dari dua sisi yaitu sisi siswa dan dari sisi guru. Dari sisi siswa, hasil belajar merupakan tingkat perkembangan mental yang lebih baik bila dibandingkan pada saat sebelum belajar. Tingkat perkembangan mental tersebut terwujud pada jenis-jenis ranah kognitif, afektif, dan psikomotor. Sedangkan dari sisi guru, hasil belajar merupakan saat terselesikannya bahan pelajaran. Hasil juga bisa diartikan adalah bila seseorang telah belajar akan terjadi perubahan tingkah laku pada orang tersebut, misalnya dari tidak tahu menjadi tahu, dan dari tidak mengerti menjadi mengerti.

Hasil belajar merupakan suatu puncak proses belajar. Hasil belajar tersebut terjadi terutama berkat evaluasi guru. Hasil belajar dapat berupa dampak pengajaran dan dampak pengiring. Kedua dampak tersebut bermanfaat bagi guru dan siswa. 
Hasil belajar dapat dicapai melalui tiga kategori ranah antara lain kognitif, afektif, psikomotor. Perinciannya adalah sebagai berikut.

a. Ranah Kognitif

Berkenaan dengan hasil belajar intelektual yang terdiri dari 6 aspek yaitu pengetahuan, pemahaman, penerapan, analisis, sintesis dan penilaian.

b. Ranah Afektif

Berkenaan dengan sikap dan nilai. Ranah afektif meliputi lima jenjang kemampuan yaitu menerima, menjawab atau reaksi, menilai, organisasi dan karakterisasi dengan suatu nilai atau kompleks nilai.

c. Ranah Psikomotor

Meliputi keterampilan motorik, manipulasi benda-benda, koordinasi neuromuscular (menghubungkan, mengamati).

Tipe hasil belajar kognitif lebih dominan daripada afektif dan psikomotor karena lebih menonjol, namun hasil belajar psikomotor dan afektif juga harus menjadi bagian dari hasil penilaian dalam proses pembelajaran di sekolah. Hasil belajar digunakan oleh guru untuk dijadikan ukuran atau kriteria dalam mencapai suatu tujuan pendidikan. Hal ini dapat tercapai apabila siswa sudah memahami belajar dengan diiringi oleh perubahan tingkah laku yang lebih baik lagi.

Pada dasarnya, pengungkapan hasil belajar meliputi segenap aspek psikologis, dimana aspek tersebut berangsur berubah seiring dengan pengalaman dan proses belajar yang dijalani siswa. Akan tetapi tidak dapat semudah itu, karena terkadang untuk ranah afektif sangat sulit dilihat hasil belajarnya. Hal ini disebabkan karena hasil belajar itu ada yang bersifat tidak bisa diraba. Maka dari itu, yang dapat dilakukan oleh guru adalah mengambil cuplikan perubahan tingkah laku sebagai hasil dari belajar yang dianggap penting dan diharapkan dapat mencerminkan hasil dari belajar tersebut, baik dari aspek cipta (kognitif), aspek rasa (afektif), aspek karsa (psikomotorik). Ada sebelas indikator/tolak ukur bahwa pembelajaran dapat dikategorikan berhasil yaitu:

a. Metode Pembelajaran:

1) Kegiatan belajar peserta didik menggunakan metode pembelajaran yang bervariasi (wawancara, pengamatan, bermain peran, penelitian, berlangsung di luar dan di dalam kelas) sesuai dengan mata pelajaran. Idealnya lebih dari 3 jenis.

2) Kegiatan belajar peserta didik menggunakan metode pembelajaran yang sesuai dengan spesifikasi bahan ajar.

3) Penggunaan metode dalam kegiatan belajar peserta didik sesuai dengan RPP

b. Pengelolaan Kelas:

1) Kegiatan belajar peserta didik variatif (individual, berpasangan , kelompok, klasikal).Idealnya lebih dari 3 jenis.

2) Kelompok belajar peserta didik beragam (gender, sosial- ekonomi, intelegensi). Idealnya lebih dari 3 variabel.

3) Keanggotaan kelompok belajar berubah-ubah sesuai kebutuhan belajar (sesuai KD, materi, metode, dan alat bantu belajar).

4) Kegiatan pembelajaran menggunakan tata tempat duduk (meja/kursi) yang memudahkan peserta didik berinteraksi dengan guru maupun dengan peserta didik lainnya. Idealnya lebih dari 3 variasi tata tempat duduk.

5) Tata tertib kelas dibuat (dan disepakati) bersama antara peserta didik dan guru. Idealnya murni inisiatif peserta didik (khusus kelas tinggi). 
c. Keterampilan Bertanya:

1) Pertanyaan yang diajukan guru dapat memancing/mendukung peserta didik dalam membangun konsep/gagasannya secara mandiri.

2) Guru mengajukan pertanyaan selalu memberikan jeda (waktu tunggu) yang memberikan keleluasaan seluruh peserta didik untuk berfikir, lalu menunjuk peserta didik yang harus menjawab tanpa pilih kasih secara acak.

3) Guru juga mendorong peserta didik untuk bertanya, berpendapat dan/atau mempertanyakan gagasan guru/peserta didik lain.

4) Peserta didik menjawab pertanyaan guru dengan lebih dulu mengacungkan tangan tanpa suasana gaduh.

5) Peserta didik berani bertanya, berpendapat dan/atau mempertanyakan pendapat baik secara lisan/tulisan.

d. Pelayanan Individual:

1) Terdapat program kegiatan belajar mandiri peserta didik yang terencana dan dilaksanakan dengan baik. Peserta didik dapat menyelesaikan tugas /permasalahannya dengan membaca, bertanya atau melakukan pengamatan dan percobaan.

2) Guru melakukan identifikasi, merancang, melaksanakan, mengevaluasi dan menindaklanjuti Program Pembelajaran Individual (PPI) sebagai respon adanya kebutuhan khusus (hiperaktif, autis, lamban, dsb).

3) Kegiatan pembelajaran melayani perbedaan individual (tipe belajar, peserta didik: audio,visual, motorik, audio- visual, audio-visual- motorik) menggunakan multimedia.

4) Peserta didik melakukan kegiatan membaca dan menulis atas keinginan sendiri dan di dokumentasikan.

e. Sumber Belajar dan Alat Bantu Pembelajaran

1) Guru menggunakan berbagai sumber belajar (sudut baca, perpustakaan, lingkungan sekitar) yang sesuai dengan kompetensi yang dikembangkan. Guru membuat alat bantu pembelajaran sesuai dengan kompetensi yang dikembangkan sendiri dan /atau bersama peserta didik/orangtua peserta didik. Guru trampil/menguasai alat bantu pembelajaran yang tersedia dan sesuai dengan materi yang diajarkan.

2) Lembar kerja mendorong peserta didik dalam menemukan konsep/gagasan/rumus/cara (tidak hanya mengerjakan perintah) dan dapat menerapkannya dalam konteks kehidupan nyata sehari- hari.

f. Umpan Balik dan Evaluasi

1) Guru memberikan umpan balik yang menantang (mendorong peserta didik untuk berpikir lebih lanjut) sesuai dengan kebutuhan peserta didik.

2) Guru memberikan umpan balik (lisan/tulisan) secara individual.

3) Guru menggunakan berbagai jenis penilaian (tes dan non tes) dan memanfaatkannya untuk kegiatan tindak lanjut.

4) Setiap proses dan hasil pembelajaran disertai dengan reward/penghargaan dan pengakuan secara verbal dan/atau non verbal.

g. Komunikasi dan Interaksi

1) Bantuan guru kepada peserta didik dalam pembelajaran bersifat mendorong untuk berfikir (misalnya dengan mengajukan pertanyaan kembali).

2) Setiap pembelajaran terbebas dari ancaman dan intimidasi (yang ditandai: tidak ada rasa takut, labelling, bulliying, anak menikmati, guru ramah).

3) Setiap proses pembelajaran bebas dari perlakuan kekerasan (emosional, fisik, pelecehan seksual). 
4) Perilaku warga kelas (peserta didik dan guru) sesuai dengan tata tertib yang dibuat bersama dan ketika yang berlaku peserta didik mendengarkan dengan baik ketika guru atau peserta didik lain berbicara.

5) Komunikasi terjalin dengan baik antara guru peserta didik dan peserta didik.

h. Keterlibatan Peserta didik

1) Peserta didik aktif dan asyik berbuat /bekerja dalam setiap kegiatan pembelajaran.

2) Guru selalu memberikan kesempatan kepada peserta didik untuk tampil di depan kelas untuk menyajikan/mengemukakan/melakukan sesuatu.

3) menuliskan/mengungkapkan

4) Dalam setiap kerja kelompok ada kejelasan peran masing masing peserta didik dan terlaksana secara bergilir.

i. Refleksi

1) Setiap usai pembelajaran guru meminta peserta didik menuliskan/mengungkapkan kesan dan keterpahaman peserta didik tentang apa yang telah dipelajari.

2) Guru melaksanakan refleksi/perenungan tentang kekuatan dan kelemahan pembelajaran yang telah dilaksanakan.

j. Hasil Karya Peserta didik

1) Berbagai hasil karya peserta didik dipajangkan, ditata rapi dan diganti secara teratur sesuai perkembangan penyampaian materi pembelajaran.

2) Hasil karya peserta didik adalah murni karya /buatan peserta didik sendiri.

k. Hasil Belajar

1) Hasil belajar peserta didik memenuhi kriteria ketuntasan minimal (KKM).

2) Peserta didik mengalami peningkatan kompetensi personal/sosial sesuai dengan potensinya (kerjasama, toleransi, menyelesaikan konflik secara sehat, bertanggung jawab dan kepemimpinan).kesempatan kepada peserta didik untuk tampil di depan kelas untuk menyajikan/mengemukakan/melakukan sesuatu.

3) Dalam setiap kerja kelompok ada kejelasan peran masing- masing peserta didik dan terlaksana secara bergilir.

\section{Metode Penelitian}

Penelitian ini menggunakan pendekatan kualitatif, yaitu "prosedur penelitian yang menghadirkan data deskriptif beberapa kata-kata tertulis atau lisan dari orang- orang atau pelaku yang dapat diamati”. Dalam penelitian kualitatif data yang dikumpulkan bukan angkaangka, akan tetapi berupa kata-kata ataugambaran. Data yang dimaksud berasal dari wawancara, catatan lapangan, foto, dokumen pribadi dan lainnya. Penelitian kualitatif digunakan untuk mengungkap data deskriptif dari informasi tentang apa yang mereka lakukan dan yang mereka alami terhadap focus penelitian.

Sesuai dengan tema yang peneliti bahas, penelitian ini menggunakan jenis penelitian lapangan (field research), dimana penelitian ini dilakukan langsung dilapangan yaitu di SMPN 12 Kota Bandar Lampung untuk mendapatkan data yang diperlukan yaitu penerapan bimbingan belajar dalam meningkatkan hasil belajar peserta didik. 


\section{Hasil dan Pembahasan}

Berdasarkan hasil observasi dan wawancara yang telah dilakukan peneliti di SMP N 12 Kota Bandar Lampung diperoleh data bahwa penerapan bimbingan belajar dalam meningkatkan hasil belajar di SMP N 12 Kota Bandar Lampung sebagai berikut:

1. Menunjukkan cara-cara belajar yang efektif

Pada tahap ini seorang pembimbing diharapkan membantu peserta didik yang menghadapi permasalahan bisa menghilangkan atau menyingkirkan kesulitan yang dihadapinya. Bantuan yang diberikan kepada peserta didik berupa cara untuk menghilangkan kesulitan sesuai dengan sebab-sebab yang melatar belakangi kenapa peserta didik itu menampilkan tingkah laku atau hasil yang seperti yang pembimbing ketahui. Adapun langkah-langkah yang dilakukan oleh konselor untuk menangani penyebab utama dari kesulitan belajar yaitu rasa malas, adalah sebagai berikut:

a. Memberi sentuhan pada titik peka anak

Sebagai pendidik bagi anak, guru Bimbingan Konseling harus memiliki kesabaran untuk memulai menyentuh titik peka anak dengan memberi perhatian khusus pada halhal yang amat menarik perhatian anak. Hal ini perlu dilakukan untuk memperoleh tanggapan dan perhatian anak. Dengan demikian anak tentunya akan terbuka menerima pendapat dengan perasaan senang dan gembira, bebas dari perasaan tertekan, takut dan terpaksa. Pada akhirnya anak akan menerima pemahaman, betapa penting dan dibutuhkan proses belajar untuk mencapai tujuan (memperoleh keperkasaan menurut daya nalarnya). Dalam hatinya pun tergerak untuk melakukan dan merencanakan kegiatan belajarnya. Hanya saja di sini dibutuhkan kesabaran anda untuk melakukan pendekatan kepada anak.

Ibu Yurdiningsih selaku guru Bimbingan Konseling di SMP N 12Kota Bandar Lampung menyatakan : "Dalam rangka membantu peserta didik meningkatkan hasil belajarnya, penerapan bimbingan konseling yang saya lakukan adalah dengan memberi perhatian yang penuh kepada peserta didik yang mengalami kesulitan belajar, dengan demikian peserta didik tidak merasa takut dan malu untuk mengutarakan berbagai persoalan yang dialami baik masalah di dalam keluarga maupun di dalam sekolah sehingga kita dapat membantu mencari jalan keluarnya”.

b. Membangkitkan nilai plus anak

Setiap guru tentunya menginginkan peserta didiknya terpacu semangatnya untuk belajar. Anak belajar atas inisiatif, kesadaran sendiri dan proses belajar itusudah menjadi suatu kesadaran kebutuhannya untuk mencapai suatu kecakapan khusus serta ingin menonjolkan kelebihan- kelebihannya lebih dari yang lainnya.

Ibu Yurdiningsih selaku guru Bimbingan Konseling di SMP N 12 Kota Bandar Lampung menyatakan: Hal yang saya lakukan untuk menyentuh perasaan atau keinginan bawah sadar anak agar dirinya merasa tertantang untuk berbuat sesuatu/melakukan sesuatu yang positif adalah dengan mengambil contoh dari tokohtokoh yang sukses. Saya mengungkapkan kepada anak-anak bahwa untuk menjadi orang yang sukses dibutuhkan perencanaan belajar, cara-cara belajar yang baik, tahu apa yang hendak dipelajari dan tahu menerapkan apa yang dipelajari, sehingga tertanam pemahaman belajar yang bukan asal belajar.

c. Mengembangkan cita-cita anak

Dalam mengembangkan cita-cita anak, guru Bimbingan Konseling ditunttut untuk berperan aktif untuk mendorong anak agar memiliki cita-cita hidup sesuai dengan taraf perkembangan daya nalarnya dan usianya. Cita-cita anak selalu berubah sesuai dengan perkembangan usia dan daya nalar anak. Guru Bimbingan Konseling dapat memberi 
contoh agar anak mau mengembangkan imajinasi dirinya atau mengidentifikasikan dirinya jika sudah dewasa ingin menjadi apa drinya. Dengan terpatrinya sebuah cita-cita hidup dalam hati nurani anak, akan menumbuhkan motivasi instrinsik pada diri anak untuk lebih giat belajar dan lebih terbuka untuk mengembangkan perencanaan belajarnya.

Ibu Yurdiningsih selaku guru Bimbingan Konseling di SMP N 12 Kota Bandar Lampung menyatakan : Hal- hal yang perlu diperhitungkan dalam menentukan waktu belajar anak di rumah yaitu sesuaikan dengan keinginan anak, jangan berbenturan dengan waktu keinginan-keinginan lain yang dominan pada anak, seperti ingin menonton film kartun favoritnya, dan sebagainya, kondisi fisik dan psikis anak dalam keadaan fresh (segar) bebas dari rasa lelah, mengantuk,gangguan penyakit, rasa marah dan sebagainya, mengembangkan tujuan belajar dan agar anak mengetahui mafaat dan arah yang dipelajarinya, biasakan akan belajar dengan bertujuan. Dengan adanya tujuan belajar akan lebih bermakna, karena anak mengetahui dengan jelas apa yang hendak dipelajari dan apa yang dikuasainya. Anak pun akan mudah memusatkan perhatian pada pelajarannya.

d. Mengembangkan cara-cara belajar yang baik pada anak

Gairah belajar anak akan tumbuh jika dirinya mengetahui bagaimana cara belajar yang efektif dan efesien. Untuk mencapai tujuan belajar anak, guru Bimbingan Konseling perlu membekali anak bagaimana cara-cara belajar yang efektif dan efesien. kita dapat mananamkan pengertian pada anak bahwa dalam belajar juga sangat dibutuhkan teknik belajar yang baik, agar belajar itu lebih bermakna dan memudahkan pencapaian tujuan belajar.

e. Mengembangkan rasa percaya diri anak

Sudah tentu menjadi suatu keharusan bagi guru Bimbingan Konseling untuk bisa membangkitkan dan memupuk rasa percaya diri anak sedini mungkin. Rasa percaya diri adalah sumber motivasi yang besar bagi anak untuk memusatkan perhatian pada pelajarannya. Dengan adanya percaya diri pada anak, akan tumbuh semangat "dia mampu berbuat atau melakukan". Sesuatu yang sulit dalam pelajaran mejadi tantangan untuk ditaklukkan dan utnuk dikuasai. Anak punya keyakinan mampu melakukan tidak akan gampang menyerah dalam menghadapi kesulitan atau hambatan dalam belajar. Kreativitas dan imajinasi berpikir akan berkembang untuk mencari cara-cara mengatasi kesulitan.

Guru Bimbingan Konseling di SMP N 12 Kota Bandar Lampung menyatakan: "Selaku guru Bimbingan dan Konseling, saya dituntut untuk melakukan peranan dalam memberikan bimbingan dan arahan kepada peserta didik agar rasa percaya diri anak dapat berkembang dengan baik, dengan langkah ini diharapkan semua persoalan yang dihadapi anak didik dalam masalah kesulitan belajar karena rasa malas dapat diantisipasi sedini mungkin".

\section{Simpulan dan Saran}

Berdasarkan uraian pada bab-bab sebelumnya, dapat diambil kesimpulan bahwa penerapan bimbingan belajar dalam meningkatkan hasil belajar peserta didik di SMP Negeri 12 Kota Bandar Lampung Tahun Pelajaran 2015/2016 adalah dengan menunjukkan cara-cara belajar yang efektif yaitu memberikan bimbingan teknis tentang belajar sehingga kesulitan belajar yang dialami dapat diselesaikan, membantu mempersiapkan diri dalam mengerjakan tugas dan ujian sehingga memiliki persiapan dalam menerima ujuan dan tugas-tugas yang 
diberikan, menunjukkan cara-cara menghadapi kesulitan dalam belajar yaitu dengan mengidentifikasi kasus, mengidentifikasi masalah, melakukan diagnosis, melakukan prognosis, melakukan treatment dan melakukan evaluasi dan tindak lanjut dan membantu dalam pengembangan bakat dan kariernya dimasa depan yaitu dengan mengenal potensi, minat, bakat yang ada dalam diri peserta didik kemudian memberikan bimbingan untuk menentukan pilihan akan melanjutkan ke jurusan apa setelah lulus sekolah.

Berdasarkan uraian kesimpulan di atas, maka pada kesempatan ini peneliti mengajukan beberapa saran kepada pihak- pihak terkait antara lain: Kepala pihak SMP Negeri 12 Kota Bandar Lampung agar membuat kebijakan yang berkenaan dengan penyediaan sarana bimbingan konseling yang lebi referesentatif dan memberi dukungan penuh terhadap penerapan bimbingan belajar sehingga dapat dilaksanakan oleh konselor. Kepada guru Bimbingan Konseling agar membuat inovasi-inovasi baru dalam melakukan bimbingan belajar kepada peserta didik sehingga proses bimbingan yang dijalankan dapat meningkatkan motivais belajar yang pada akhirnya hasil belajar peserta didik dapat meningkat. Kepada peserta didik agar serius dan sungguh-sungguh dalam mengikuti bimbingan belajar yang dilakukan oleh konselor sehingga dapat berdampak terhadap kebiasaan belajar yang pada pada akhirnya hasil belajar peserta didik dapat meningkat.

\section{Daftar Pustaka}

Abu Bakar Braja, Psikologi dan Teknik Konseling, (Jakarta: Studia Press, 2004), cet. II.

Agus Suyanto, Bimbingan Kearah Belajar yang Sukses, (Jakarta: Bulan Bintang, 2001), cet ke vi.

Ahmadi dan Uhbiyanti, Cara Belajar yang Efektif, (Yogyakarta: PUBIB, 2008).

Anni Mulyani, Belajar dan Pembelajaran, (Jakarta: Rineka Cipta, 2009).

Burhan Bungin, Analisis Data Penelitian Kualitatif : Pemahaman Filosofis dan Metodologis ke Arah Penguasaan Model Aplikasi, (Jakarta: Raja Grafindo Persada, 2003).

Cholid Narbuko dan Abu Ahmad, Metodologi Penelitian, (Jakarta: Bumi Aksara, 1997).

Dalyono, Psikologi Pendidikan, (Semarang: IKIP Semarang Press, 2007).

Daryanto, Evaluasi Pendidikan, (Jakarta: Rineka Cipta, 2007).

Depdikbid, Peraturan Pemerintah Republik Indonesia Nomor 18 tahun 2003 tentang Standar Pendidikan Nasional, (Jakarta: 2003).

Dewa Ketut Sukardi, Dasar-Dasar Bimbingan dan Penyuluhan di Sekolah, (Surabaya: Usaha Nasional, 2003), edisi revisi keempat.

Pengantar Pelaksanaan Program Bimbingan dan Konseling di Sekolah, (Jakarta: Rineka Cipta, 2000) .

Djumhur dan Mohammad Surya, Bimbingan dan Penyuluhan di Sekolah, (Bandung: Ilmu, 2005), edisi revisi ketiga.

H.B. Sutopo, Metodologi Penelitian Kualitatif, (Surakarta: Sebelas Maret University Press, 2002).

Hellen A, Bimbingan dan Konseling, (Jakarta: Ciputat Press, 2002), cet. 1

Imam Suprayogi dan Tobroni, Metodologi Penelitian Sosial Agama, (Bandung: Remaja Rosda Karya, 2003). 
Imam Utama, Membangun Kebiasaan Belajar dalam Diri Siswa, (Bandung: Remaja Rosdakarya, 2002).

Kartini Kartono, Bimbingan dan Dasar-dasar Pelaksanaannya, (Jakarta; Rajawali Bina Aksara, 2003).

Pengantar Metodologi Riset Sosial, (Bandung: Alumni Madar Maju, Cetakan IV, 2006).

Koenjaraningrat, Metode-metode Penelitian Masyarakat, (Jakarta: Gramedia Pustaka Utama, Cet. ke 4, 2003).

Lexy J. Moleong, Metodologi Penelitian Kualitatif, (Bandung: Remaja Rosda Karya, 2002).

Moh. Surya, Bimbingan Belajar Sukses, (Surabaya : Bina Ilmu, 1998).

Muhammad Fariska, Kualitas Belajar Mengajar, (Bandung: Remaja Rosdakarya, 2003).

Muhammad Umar dan Sartono, Bimbingan dan Penyuluhan, (Bandung: Pustaka Setia, 2008).

Muhibbin Syah, Psikologi Belajar, (Jakarta: Logos Wacana Ilmu, 2005).

Nana Sudjana, Penilaian Hasil Proses Belajar Mengajar, (Bandung: Remaja Rosdakarya, 2005). ketiga.

, Tuntunan Menyusw Karya Ilmiah, (Jakarta: Sinar Baru, 2007), Edisi Revis

Nawawi Nurdin, Urgensitas Evaluasi Pembelajaran, (Jakarta: Rajawali Press, 2002).

Ngalim Purwanto, Prinsip-prinsip dan Teknik Evaluasi, (Bandung: Remaja Rosdakarya, 2001).

Prayitno, dkk., Pedoman Khusus Bimbingan dan Konseling, (Jakarta: Depdiknas, 2003).

Rohman Ali. Bimbingan Konseling : Telaah Fungsi dan Peran), (Jakarta: Media Amanah, 2007), edisi Revisi kedua.

S. Nasution, Metode Research : Penelitian Ilmiah, (Jakarta: Bumi Aksara, 2011), Cet kesebelas. , Metodologi Penelitian Dasar, (Jakarta: Bulan Bintang, 1994).

Sardiman AM., Interaksi dan Motivasi Belajar Mengajar, (Jakarta: Raja Grafindo Persada, 2004).

Suharsimi Arikunto, Dasar-dasar Evaluasi Pendidikan, (Jakarta: Bumi Aksara, 2009).

Sutrisno Hadi, Metodologi Research, (Yogyakarta: Fakultas Psikologi UGM., 1986), Jilid I.

Syaiful Bahri Djamarah, Psikologi Belajar, (Jakarta: Rineka Cipta, 2002).

Syamsu Yusuf LN, A. Juntika Nurihsan, Landasan Bimbingan dan Konseling, (Bandung: Rosda Karya, Cet. I, 2005).

Tim Sinar Grafika, Himpunan Perundang-undangan R1 Tentang Sistem Pendidikan Nasional (SISDIKNAS). (Jakarta : Sinar Grafika, 2003).

Winarno Surahmad, Dasar dan Tehnik Research, (Bandung: Tarsito, 2001), cet. III.

WS. Winkel, Bimbingan dan Konseling di Institusi Pendidikan, (Jakarta: Gramedia, 2002), cet. $\mathrm{Ke}-4$.

Yusuf Gunawan, Pengantar Bimbingan dan Konseling, (Jakarta: Gloria Indonesia, 2001). 